\title{
EARLY SUGGESTION FOR AN INEBRIATE ASYLUM.
}

The wisdom of maintaining at public expense a hospital for dipsomaniacs or inebriates is a subject now on the anvil of political discussion. The following letter written sometime in the month of September, 1863, will prove of interest.

Hon. I. M. Preston, Marion:

Sometime ago, you and I had some talk about our Lunatic Asylum, and $I$ promised to put some ideas $I$ then stated, in writing, and address them to you, which $\mathrm{I}$ now do, hoping that, in this way, the subject may be brought before the next session of the General Assembly either by the Linn County delegation or some other, and the matter looked to, and examined.

$I$ believe that a man, who, being in all other respects clear in his intellect, has yet lost the power to resist the temptation of getting drunk, and becomes, in consequence, a periodical drunkard,

- is insane. He is no more master of his actions, while drinking, than a man insane from any other cause, and, even in his sober intervals, is not entirely master of himself.

But if such a man could be put under restraint from liquor for a sufficient time, he might acquire strength to abstain voluntarily; and if such restraint were possible under our law, some of the most brilliant men we have today, in the state, might be saved. You and $I$, and every man in every locality know instances of the kind to which I here allude. I believe that the state has a right to take custody of such men, on the complaint of their friends, and treat them for a time as insane; and I believe they, themselves, would be thankful for such treatment; because although they have lost all power of will to resist the opportunity of getting drunk, they are not blind to the destructive consequences.

If these ideas should be entertained, the State Lunatic Asylum, or a branch of it, might afford the necessary accommodations for a time. But an Inebriate Asylum, built somewhere in the center of the State is the thing to be ultimately looked to. A state takes rank as much from its charitable institutions as from its roads, or anything else. As to the expense, the State can bear it very well. You remember we were told in the sessions of 1855 , that we should be ruined by appropriating so much for the Lunatic Asylum; but the State is not ruined yet, and has got an institution that is an honor to it. If you think as I do on this subject, try and turn public attention to it, and especially the attention of your county delegation to the next General Assembly. The more the subject is examined the stronger, I believe, will grow the conviction of the necessity of adopting some measure in the direction I am trying to point out.

W. W. Hamilton.

Cascade. 
Copyright of Annals of Iowa is the property of State of Iowa, by \& through the State Historical Society of Iowa and its content may not be copied or emailed to multiple sites or posted to a listserv without the copyright holder's express written permission. However, users may print, download, or email articles for individual use. 